\title{
Efectos de los modos de hablar (nos): escuela de radio. Alternativas de enseñanzas de la Lengua y la Literatura en nivel secundario (tercer año) ${ }^{(1)}$
}

\author{
Rosario Caminos, Martin Duarte, Micaela Lorenzotti ${ }^{(2)}$
}

(1) Este trabajo fue elaborado en el marco del Seminario Teorías de los aprendizajes correspondiente a la Maestría en Didácticas Específicas de la Facultad de Humanidades y Ciencias de la Universidad Nacional del Litoral y oportunamente reformulado.

(2) Profesores de Letras y estudiantes de la Maestría en Didácticas Específicas de la

Facultad de Humanidades y Ciencias, Universidad Nacional del Litoral. E-mail: rcaminos@unl.edu.ar martinm_duarte@hotmail.com micaelaluz@live.com
Palabras clave. aula de lengua y literatura . clase hipertextual · interactividad . evaluación formativa

Resumen. En los últimos años se ha ido transformando el escenario sociocultural en el que se insertan nuestras prácticas educativas. El desafío actual de las aulas es la imperiosa necesidad de trabajar con alumnos que son cibernautas, que están hiperconectados e hiperestimulados. Frente a este desafío entendemos que debemos proponer un cambio de rumbo y dejar de lado la clase lineal procurando la venida de una clase viva, en sentido hipertextual, con movimiento propio, que sale de sus cauces «tradicionales» para tomar forma a partir de las relaciones intersubjetivas propias del aula. En este ensayo se presenta como caso de análisis un proyecto de radio escolar llevado a cabo en un barrio periférico de la ciudad de Santa Fe, el barrio Santa Rosa de Lima. El objetivo que se propone tal proyecto es enseñar Lengua y Literatura en una relación de transversalidad con otras materias del currículum escolar enmarcando los contenidos en un producto final, una radio barrial. Esta propuesta supone una reconceptualización del aula en tanto se la piensa como una subcomunidad de aprendices mutuos en donde cada individuo trabaja mancomunadamente para el logro de un objetivo compartido: la concreción de un programa radial. 
Keywords. Language and Literature class room . hypertextual class $\cdot$ interactivity $\cdot$ formative evaluation

Abstract. In the last years the sociocultural scenario in which our educatives practices are inserted. The actual challenge in the class rooms are the imperative needs of work with students that are netizens, which are hyperconnected and hyperstimulated. To face this challenge, we understand that we have to propose a change of course, leaving aside the linear way of a class, seeking the introduction of a live class, in a hypertextual way, with its own movement, that move out from its «tradititional» roots to take form from the own intersubjective class rooms relationships. In this essay, an analysis case is presented consisted in a school radio show project that takes place in a suburb located in Santa Fe city, the Santa Rosa de Lima neighborhood. The objective this project is proposing is to teach Language and Literature in crooscutting relationship with others subjects of the curricula, turning the contents in a final product, a neighborhood radio show. This proposal aim to a reconceptualization of the class room, if this is thought that a subcommunity of mutual apprentices in which each one work with each other for the reach of a common goal: the success of the radio show.

FANTÁSTICO. Es la palabra con que designamos lo insólito. Por eso se aplica continuamente en los viajes y en la historia del pensamiento. No es que designe cosas de contenido mágico: simplemente designa otras cosas. (Ernesto Sábato)

La enseñanza no es ajena a los signos que la caracterizan como altamente compleja. Complejidad que deviene en gran medida del hecho de que se desarrolla en escenarios singulares, bordeados y surcados por el contexto. (Gloria Edelstein)

\section{Partir de lo que sabemos para potenciar los «vicios» del contexto}

Sabemos que como profesores de Lengua y Literatura nos incumbe trabajar con alumnos cibernautas que tienen el ADN de las ventanitas de Microsoft, que están hiperconectados, hiperestimulados y son hijos del zapping. Sabemos que las condiciones de enseñanza se ven alteradas por la sociedad informacional y que esto puede alarmarnos. Sabemos que no tiene sentido añorar nostálgicamente el medio sólido de la institución estatal. Sabemos que resulta imperioso aprender 